\title{
ФАЗОВЫЕ ФОРМЫ ЗОЛОТА В СИСТЕМЕ КОРЕННОЙ ИСТОЧНИК - ВТОРИЧНЫЙ ОРЕОЛ ПРИ ФОРМИРОВАНИИ АНОМАЛЬНЫХ ГЕОХИМИЧЕСКИХ ПОЛЕЙ
}

\author{
Т. Н. Полякова ${ }^{1}$, А. Г. Пилицын ${ }^{2}$, А. А. Кременецкий ${ }^{2}$ \\ ${ }^{1}$ Воронежский государственный университет \\ ${ }^{2}$ Институт минералогии, геохимии и кристаллохимии редких элементов, г. Москва
}

Поступила в редакцию 14 февраля 2018 г.

\begin{abstract}
Аннотация: на примере золоторудных объектов Полярного Урала и Енисейского кряжа рассмотрены формы нахождения золота в коренных рудах и элювиально-делювиальных отложениях остаточного ореола рассеяния. Предложена модель перераспределения фазовых форм Аи в системе коренной источник - вторичный ореол для интерпретачии АГХП сульфидсодержащих и мало-, убогосульфидных золоторудных объектов на перекрытых территориях. Установлено, что в пределах рудных зон непосредственно над коренным источником в рыхлых отложениях присутствуют и зерновые, и сорбиионные формы золота. По мере удаления от рудного объекта роль сорбиионных форм возрастает, а за пределами рудного поля в делювии могут наблюдаться только ксеногенные зерновые частицы.
\end{abstract}

Ключевые слова: поисковая геохимия, золото, фазовые формы, модель.

\section{PHASE FORMS OF GOLD IN THE SYSTEM OF 'ORE BODY - SECONDARY DISPERSION PATTERN' IN ABNORMAL GEOCHEMICAL FIELDS FORMATION}

\begin{abstract}
: phase forms of gold in the ore bodies, crust of weathering and residual-talus accumulations of secondary dispersion halo have been studied in the objects of the Polar Urals and Yenissey Ridge. Within the overlapped areas of sulfur-bearing and low-sulfur gold ore objects, the model of Au phase forms redistribution in the system of 'ore body - secondary dispersion pattern' in the abnormal geochemical fields interpretations has been suggested. It has been found out that within the ore zones, located directly over the ore bodies, both granular and sorption-type forms of gold in the residual soils are present. As the distance from the ore body increases, the number of sorption-type forms of gold gradually rises as well, whereas beyond the ore field talus deposits contain solely xenogeneic granular particles of gold.

Key words: applied geochemistry; gold deposits; phase form; model.
\end{abstract}

Существующие в настоящее время модели зональности аномальных геохимических полей (АГХП) в зоне гипергенеза с разной степенью детальности описывают распределение в их контурах рудных и сопутствующих элементов, однако проблема влияния различных фазовых форм рудных элементов на формирование АГХП остается открытой. Известно, что твердые частицы сорбционного и зернового типа отличаются друг от друга генезисом, мобильностью, масштабом и геометрией формируемых ими ореолов рассеяния и, как следствие, обладают своим поисковым значением [1-3]. Именно эти данные лежат в основе выбора конкретных технологий проведения производственных работ геохимического направления (ГСР-200, поиски), прежде всего на перекрытых территориях, с целью повышения результативности выполняемых работ.

Таким образом, изучение закономерностей нахождения различных фазовых форм рудных компонентов в системе коренной источник - вторичный ореол с установлением роли легких (сорбционных) и тяжелых (зерновых) фракций в формировании АГХП имеет большое значение не только для решения фундаментальных вопросов теории формирования геохимических аномалий, но и для повышения эффективности поисковой геохимии.

Геологическое строение объектов исследования

Изучение фазовых форм золота в системе коренной источник - вторичный ореол проводилось на примере двух известных рудопроявлений золота: Иочиминское (Заангарская часть Енисейского кряжа) и Полярная Надежда (Полярный Урал). В геохимических полях эти объекты отчетливо фиксируются вторичными геохимическими аномалиями.

Коренные породы в пределах рудопроявления Иочиминское представлены филлитизированными глинистыми сланцами удерейской свиты $\left(\mathrm{PR}_{3}\right)$ с прожилково-жильными зонами окварцевания, которые содержат сульфидную и золоторудную минерали- 
зацию золотокварцевого геолого-промышленного типа. Из жильных минералов в составе руд преобладает молочно-белый крупнокристаллический кварц, почти постоянно в незначительных количествах встречаются карбонаты, барит, хлорит, серицит, мусковит, альбит. Сульфиды представлены, главным образом, пиритом, резко подчиненную роль играют халькопирит и тетраэдрит. Их распределение в рудных интервалах крайне неравномерное, на отдельных участках содержание сульфидов достигает $40 \%$, однако в среднем оно не превышает 5-10 \% от общей рудной массы.

В геологическом строении рудопроявления Полярная Надежда принимают участие две нижние толщи малоуральской свиты $\left(\mathrm{S}_{2}-\mathrm{D}_{1}\right)$ - кластогенная и вулканогенно-туффитовая, а также интрузивные и дайковые породы конгорского комплекса $\left(\mathrm{D}_{3}\right)$. На рудопроявлении установлено пять рудоносных зон, формирование которых связано с контактовым воздействием дайковых тел диоритов конгорского комплекса. Золотое оруденение относится к золото-сульфидному типу и связано с зонами полисульфидной минерализации. Содержание сульфидов в рудах колеблется от 10 $15 \%$ до 35-40\%, основными рудными минералами являются пирит, сфалерит, галенит, халькопирит, тетраэдрит, теннантит, реже отмечается пирротин.

Рассмотренные объекты позволяют в интегральной системе коренной источник - вторичный ореол рассеяния выделить следующие главные элементы и зональность (снизу вверх):

- делювиальные отложения (наложенный ореол рассеяния);

- элювиальные отложения (остаточный ореол рассеяния);

- коренной источник (первичный ореол рассеяния).

\section{Методы исследований}

Фазовые формы золота в коренных источниках и элювиальных отложениях рудопроявлений Полярная Надежда и Иочиминское изучались с использованием растрового электронного микроскопа, минералогорентгено-спектрального и рационального (фазового) анализов.

Метод рационального (фазового) анализа заключался в последовательном выщелачивании золота цианидом натрия. Вскрытие минералов, содержащих золото, осуществлялось раствором соляной и азотной кислот и гидроксидом натрия при соблюдении определенных режимов. Золото в пробе и кеках после соляно- и азотнокислотных обработок анализировалось пробирным методом.

Для большей достоверности Аu определялось во всех продуктах по двум параллельным пробам.

\section{Фазовые формы золота в коренных источниках}

Минералогические исследования коренных руд рудопроявления Иочиминское позволили установить в них присутствие двух форм золота: 1) в виде тонкодисперсных и субмикроскопических вклю- чений в кварце и карбонатах и 2) в качестве «невидимых» примесей в сульфидах, главным образом, в пирите, в меньшей степени - в тетраэдрите. Содержание «невидимого» золота в пирите варьирует от 500 г/т до 800 г/T, в тетраэдрите составляет 800 г/т (табл. 1).

Таблица 1

Химический состав золотосодержащуи сульфидов из коренных руд рудопроявления Иочиминское, (\% вес.)

\begin{tabular}{|c|c|c|c|c|}
\hline \multirow{2}{*}{ Элемент } & Пирит & Пирит & Пирит & Тетраэдрит \\
\cline { 2 - 5 } & $\mathrm{C}-4-41-3$ & $\mathrm{C}-4-41-37$ & $\mathrm{C}-4-41-23$ & $\mathrm{C}-4-41-27$ \\
\hline $\mathrm{Fe}$ & 44,83 & 44,56 & 46,51 & 2,90 \\
\hline $\mathrm{Cr}$ & 0,57 & 0,42 & 0,03 & 0,18 \\
\hline $\mathrm{SiO}_{2}$ & 0,04 & 0,06 & 0,02 & 1,69 \\
\hline $\mathrm{As}$ & не обн. & 0,05 & 0,40 & 1,68 \\
\hline $\mathrm{Au}$ & 0,06 & 0,08 & 0,05 & 0,08 \\
\hline $\mathrm{Cu}$ & не обн. & 0,05 & 0,01 & 36,06 \\
\hline $\mathrm{Sb}$ & 0,01 & 0,02 & не обн. & 29,61 \\
\hline $\mathrm{Zn}$ & 0,04 & не обн. & 0,01 & 3,14 \\
\hline $\mathrm{S}$ & 52,65 & 51,40 & 52,74 & 26,09 \\
\hline $\mathrm{Cумма}$ & 98,20 & 96,64 & 99,77 & 101,43 \\
\hline
\end{tabular}

С целью выявления всех возможных форм нахождения золота в коренных породах рассматриваемого рудопроявления был выполнен рациональный (фазовый) анализ для двух проб: бороздовой (БК3), представленной окисленными золотосодержащими рудами, и керновой (С 4-41), отобранной из золотокварцевых руд. В пробе БК-3 рациональный анализ был проведен по упрощенной схеме, когда в кеки цианирования отбирали по 20 г, а также анализировали жидкую фазу операций цианирования. Кеки цианирования подвергали химическому вскрытию с последующим анализом растворов на золото атомноабсорбционным методом.

Содержание золота в исходной пробе БК-3 составило 5,4 г/т. На первой стадии цианирования раствор содержал 3,51 мг/л Аu, на последующих стадиях менее 0,07 мг/л. Анализ результатов показал, что золото в изученной пробе свободное и цианированием извлекается из разных навесок от 5 до 7 г/т.

Содержание $\mathrm{Au}$ в керновой пробе C 4-41 по данным опробования - 7,3 г/т. Предварительный минералогический анализ отмытой тонкой фракции показал значительное количество в руде сульфидов (пирит, халькопирит, галенит, сфалерит и др.) - до $20 \%$. По результатам рационального (фазового) анализа золото в изученной пробе свободное (98,8 \%), с мелкими включениями в сульфидах и кварце связано только 1,2\% Аu (табл. 2).

Таким образом, в коренных рудах рудопроявления Иочиминское золото присутствует преимущественно в виде тонкодисперсных свободных зерен, в меньшей степени - в форме субмикроскопических включений в кварце и карбонатах и в качестве «невидимых» примесей в сульфидах. 
Результаты ращионального (фазового) анализа керновой пробы

Таблица 2

\begin{tabular}{|c|c|c|}
\hline \multirow{2}{*}{ Форма нахождения золота (при данной крупности руды) } & \multicolumn{2}{|c|}{ Проба С4-41 (золото) } \\
\hline & $\Gamma / \mathrm{T}$ & $\%$ \\
\hline Золото в виде свободных металлических зерен, сростки с рудными минералами & 17,83 & 98,8 \\
\hline Золото, связанное с минералами меди (кроме халькопирита) & - & - \\
\hline Золото, покрытое окисными пленками железа и марганца & - & - \\
\hline Золото, тонковкрапленное в сульфиды (пирит, галенит, арсенопирит) & 0,19 & 1,1 \\
\hline Золото в силикатной матрице & 0,03 & 0,10 \\
\hline Итого: & 18,05 & 100,0 \\
\hline
\end{tabular}

Для золото-полиметаллических руд рудопроявления Полярная Надежда установлено присутствие золота в форме: 1) видимых выделений; 2) «невидимой» примеси в сульфидах и 3 ) собственных минеральных соединений.

Видимое золото в коренных рудах представлено включениями в сульфидах и свободными золотинами.
Микроскопические мелкие включения Аu в пирите по форме относятся к морфологической группе плохо образованных и округленных кристаллов [4]. В аншлифах они имеют вид одиночных каплевидных частиц размером не более 15-20 $\mu$ м (рис. 1) и характеризуются высокой пробностью (до 1000).
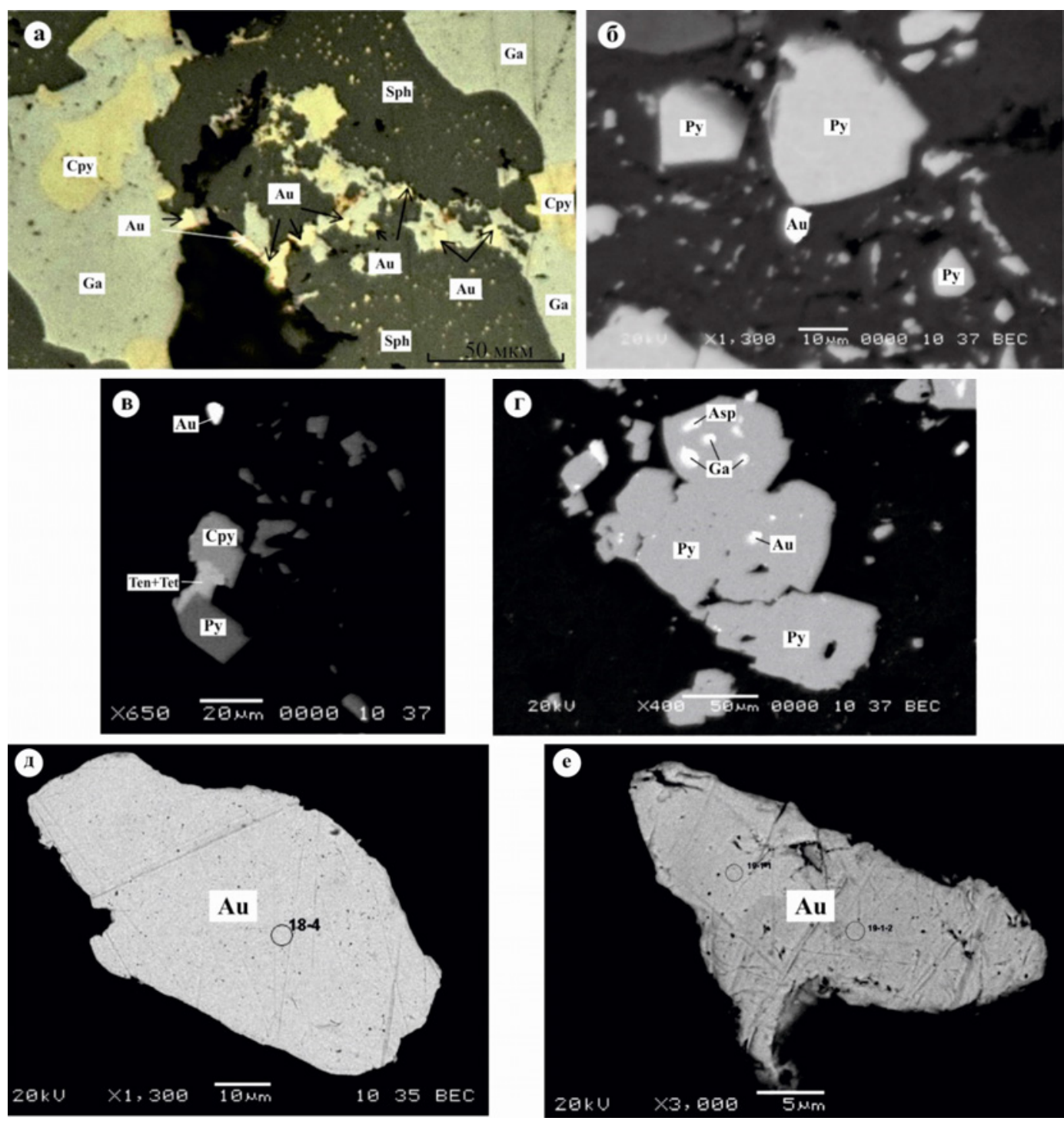

Puc. 1. Видимое золото в коренных породах рудопроявления Полярная Надежда: $a-8$ - свободные частицы самородного металла; 2 - примесь в пирите (скв. 7, глуб.: $a-26$ м, $\sigma-7$ м, в - 8,0, $2-8,1$ м; фото: $a-6$ скрещенных николях; $6-2-$ в отраженных электронах); $\partial-e-$ морфология свободных выделений самородного золота (обр. К-9-3; фото в отраженных электронах). 
Свободные выделения самородного золота в подавляющем большинстве случаев представлены гемиидиоморфными (частично ограненными) агрегатами размером от 3 до $15 \mu$, реже отмечаются более крупные (25-80 $\mu$ м) изометричные кристаллы (рис. 1).

По химическому составу все свободные частицы $\mathrm{Au}$ относятся к электруму с содержанием серебра в краевых частях до 15-17 \% (табл. 3). В отдельных золотинах примесь $\mathrm{Ag}$ наблюдается в виде пятнообразных скоплений. Подобное неравномерное распределение серебра в золоте, вероятно, связано с периодическими изменениями окислительно-восстановительных условий минералообразования. Последние могли быть следствием пульсации тектонических движений и влиянием их на стенки рудовмещающих полостей. Это приводило к падению давления, вскипанию растворов и др. [4].

«Невидимое» золото в золото-полиметаллических рудах рассматриваемого рудопроявления приурочено, главным образом, к пириту, в меньшей степени - к халькопириту и галениту. Содержание $\mathrm{Au}$ в сульфидах не превышает 800 г/т (табл. 4).

Собственные минеральные соединения золота в коренных рудах представлены единичными выделениями луаньхеита [( $\left.\mathrm{Ag}, \mathrm{Au}) \mathrm{Hg}_{3}\right]$ - минерала, отличающегося низкими температурами образования и равновесного состояния. При изменении РТ-условий луаньхеит распадается на электрум с мирмекитовой эмульсией ртути, которая в дальнейшем может покинуть минерал-хозяин, оставив его в виде микрогубчатого образования.

Из рассмотренных фазовых форм Аи в золотополиметаллических рудах рудопроявления Полярная Надежда главенствующая роль принадлежит «невидимому» золоту в сульфидах, однако, при этом количество видимого, в том числе и свободного, металла здесь значительно выше, чем в золото-кварцевых рудах рудопроявления Иочиминское.

Таблица 3

Химический состав видимого золота

в коренных породах рудопроявления Полярная Надежда (\% вес.)

\begin{tabular}{|c|c|c|c|c|c|}
\hline Форма золота & № пробы & № точки & $\mathrm{Ag}$ & $\mathrm{Au}$ & Сумма \\
\hline \multirow{15}{*}{ Свободная } & \multirow{12}{*}{ K-9-3 } & $19-1-1$ & 2,72 & 96,46 & 99,18 \\
\hline & & $19-1-2$ & 3,19 & 95,95 & 99,14 \\
\hline & & $19-2$ & 3,51 & 95,74 & 99,25 \\
\hline & & $19-2-2$ & 4,44 & 95,61 & 100,05 \\
\hline & & 19-3-1 & 2,97 & 98,23 & 101,19 \\
\hline & & $19-3-2$ & 2,37 & 97,3 & 99,67 \\
\hline & & $19-3-3$ & 2,37 & 99,3 & 101,67 \\
\hline & & $19-3-4$ & 2,94 & 97,06 & 100,00 \\
\hline & & $19-4-1$ & 1,99 & 97,35 & 99,34 \\
\hline & & $19-4-2$ & 2,02 & 96,85 & 98,87 \\
\hline & & $18-3$ & 15,77 & 84,23 & 99,99 \\
\hline & & $18-4$ & 12,61 & 87,54 & 100,15 \\
\hline & \multirow{2}{*}{ 417-1 (скв. 7, гл. 7 м) } & 1 & 7,71 & 92,27 & 99,98 \\
\hline & & 2 & 8,46 & 91,84 & 100,00 \\
\hline & 420 (скв. 7, гл. 8 м) & 1 & 17,32 & 82,68 & 100,00 \\
\hline Видимая примесь в пирите & 421 (скв. 7, гл. 8,1 м) & 1 & не.обн. & 100,00 & 100,00 \\
\hline
\end{tabular}

Химический состав золотосодержащих сульфидов

Таблица 4

из коренных руд рудопроявления Полярная Надежда, (\% вес.)

\begin{tabular}{|c|c|c|c|c|c|c|c|}
\hline \multirow{2}{*}{ Элемент } & Пирит & Пирит & Пирит & Пирит & Пирит & Халькопирит & Галенит \\
\cline { 2 - 8 } & $247-7-6$ & $247-2-12$ & $232-3-6$ & $232-3-7$ & $232-6-11$ & $232-1-2$ & $247-7-7$ \\
\hline $\mathrm{Fe}$ & 44,60 & 44,98 & 44,27 & 45,67 & 45,91 & 29,17 & 8,89 \\
\hline $\mathrm{SiO}_{2}$ & 0,09 & 0,03 & 0,33 & 0,01 & 0,01 & 0,01 & 0,03 \\
\hline $\mathrm{Au}$ & 0,08 & 0,08 & 0,08 & 0,08 & 0,05 & 0,05 & 0,05 \\
\hline $\mathrm{Cu}$ & не обн. & не обн. & 0,44 & 0,04 & не обн. & 33,27 & 0,15 \\
\hline $\mathrm{Pb}$ & 0,14 & не обн. & 0,04 & не обн. & не обн. & не обн. & 71,51 \\
\hline $\mathrm{S}$ & 52,40 & 52,17 & 51,40 & 53,03 & 54,21 & 34,73 & 20,63 \\
\hline $\mathrm{Cумма}$ & 97,31 & 97,26 & 96,56 & 98,83 & 100,18 & 97,23 & 101,26 \\
\hline
\end{tabular}




\section{Фазовые формы золота}

\section{в элювиальных отложениях}

На рудопроявлении Полярная Надежда фазовые формы нахождения золота в элювиальных отложениях исследовались в трех пробах, отобранных из зоны гидролиза (со дна поисковой канавы) в пределах рудоносной зоны.

Минералогические исследования гравиконцентратов показали, что во всех пробах золото присутствует в форме различных по размеру свободных выделений металла. Практически все частицы золота имеют неправильную форму с признаками сглаживания граней (рис. 2). По химическому составу они относятся к электруму и характеризуются зональным распределением $\mathrm{Au}$ и Ag: краевые части зерен, как правило, обеднены золотом и обогащены серебром, примесь которого может достигать $51 \%$ (табл. 5). В отдельных частицах наблюдаются микропрожилки высокопробного золота.
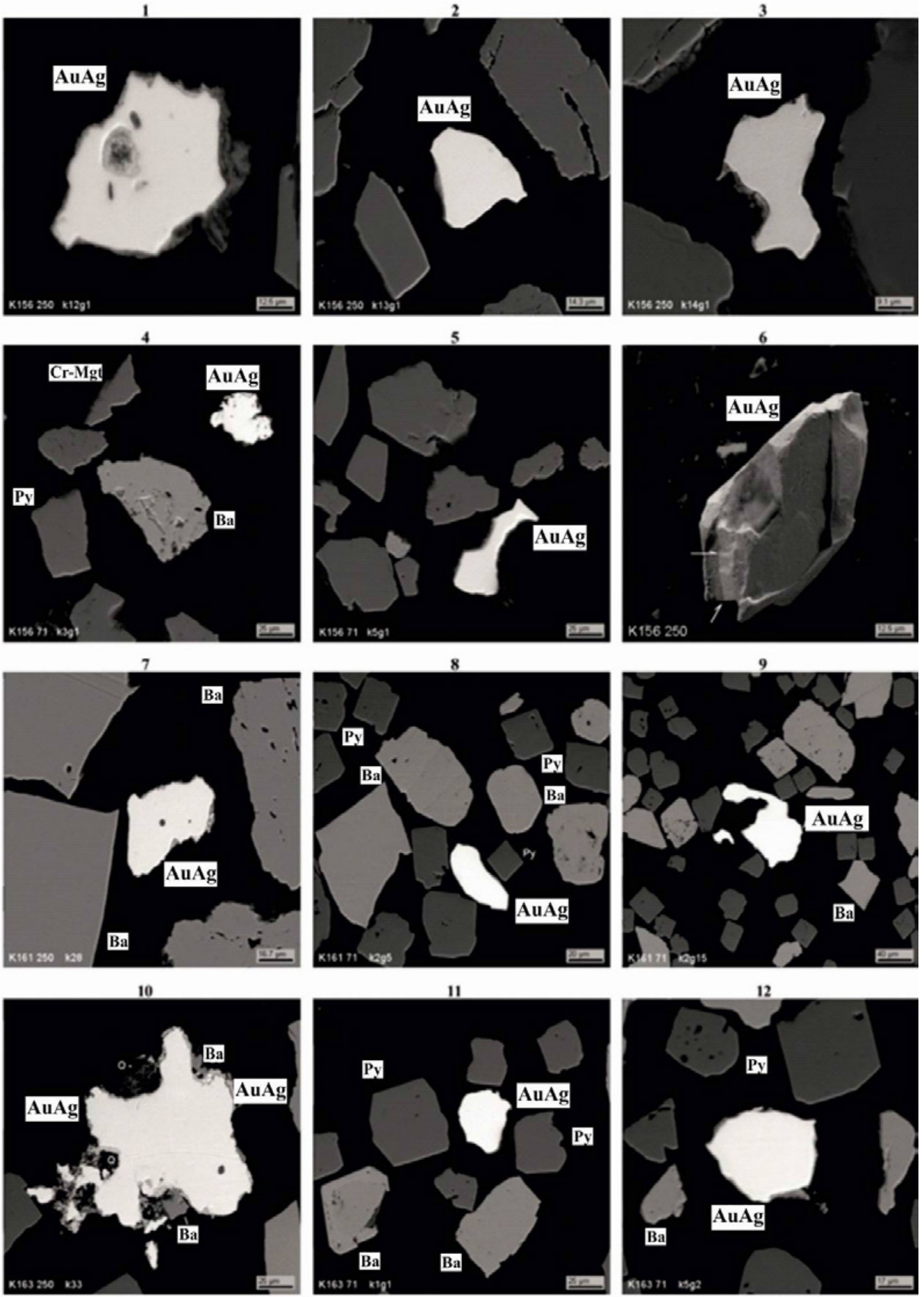

Puc. 2. Форма и размеры золота в элювиальных отложениях зоны гидролиза рудопроявления Полярная Надежда (гравиконцентраты проб). Фото 1-3, 6 - проба К156, фракция 250-71 $\mu \mathrm{m} ; 4-5$ - проба К156, фракция - $71 \mu \mathrm{m} ; 7$ - проба К161, фракция 250-71 $\mu \mathrm{m} ; 8-9$ - проба К161, фракция - $71 \mu \mathrm{m} ; 10$ - проба К163, фракция 250-71 $\mu \mathrm{m} ; 11-12$ - проба К163, фракция - $71 \mu \mathrm{m}$. 
Химический состав зерен золота в элювиальных отложениях зоны гидролиза рудопроявления Полярная Надежда

\begin{tabular}{|c|c|c|c|c|c|c|c|c|c|}
\hline Проба & Зерно & $\mathrm{Au}$ & $\mathrm{Ag}$ & Сумма & Проба & Зерно & $\mathrm{Au}$ & $\mathrm{Ag}$ & Сумма \\
\hline \multirow{2}{*}{ K156_71 } & центр & 82,9 & 16,6 & 99,5 & \multirow{2}{*}{ K161_71 } & центр & 71,8 & 27,3 & 99,1 \\
\hline & край & 73,3 & 26,7 & 100,0 & & край & 59,0 & 41,0 & 100,0 \\
\hline \multirow{2}{*}{ K156_71 } & центр & 83,8 & 15,5 & 99,3 & \multirow{2}{*}{ K161_71 } & центр & 82,1 & 17,1 & 99,2 \\
\hline & край & 74,8 & 25,2 & 100,0 & & край & 72,5 & 27,5 & 100,0 \\
\hline \multirow{2}{*}{ K156_250 } & центр & 62,4 & 36,9 & 99,3 & \multirow{2}{*}{ K161_71 } & центр & 78,1 & 21,1 & 99,2 \\
\hline & край & 48,1 & 51,9 & 100,0 & & край & 66,9 & 33,1 & 100,0 \\
\hline \multirow{2}{*}{ K156_250 } & центр & 80.8 & 18,4 & 99,2 & \multirow{2}{*}{ K161_250 } & центр & 72,7 & 26,6 & 99,3 \\
\hline & край & 70,6 & 29,4 & 100,0 & & край & 59,9 & 40,1 & 100,0 \\
\hline \multirow{2}{*}{ K156_250 } & центр & 77,9 & 21,3 & 99,2 & \multirow{2}{*}{ K161_250 } & центр & 71,3 & 28,1 & 99,4 \\
\hline & край & 66,7 & 33,3 & 100,0 & & край & 58,2 & 41,8 & 100,0 \\
\hline \multirow{2}{*}{ K156_250 } & центр & 72,0 & 27,9 & 99,9 & \multirow{2}{*}{ K163_71 } & центр & 82,0 & 17,1 & 99,1 \\
\hline & край & 58,6 & 41,4 & 100,0 & & край & 72,4 & 27,6 & 100,0 \\
\hline \multirow{2}{*}{ K156_250 } & центр & 79,7 & 19,7 & 99,4 & \multirow{2}{*}{ K163_71 } & центр & 72,6 & 26,9 & 99,5 \\
\hline & край & 68,9 & 31,1 & 100,0 & & край & 59,6 & 40,4 & 100,0 \\
\hline \multirow{2}{*}{ K156_250 } & центр & 73,5 & 26,3 & 99,9 & \multirow{2}{*}{ K163_71 } & центр & 67,5 & 31,9 & 99,4 \\
\hline & край & 60,5 & 39,5 & 100,0 & & край & 53,6 & 46,4 & 100,0 \\
\hline \multirow{2}{*}{ K156_250 } & центр & 72,9 & 27,0 & 99,6 & \multirow{2}{*}{ K163_71 } & центр & 66,2 & 33,7 & 99,9 \\
\hline & край & 59,6 & 40,4 & 100,0 & & край & 51,9 & 48,1 & 100,0 \\
\hline \multirow{2}{*}{ K161_71 } & центр & 70,9 & 28,7 & 99,6 & \multirow{2}{*}{ K163_71 } & центр & 71,2 & 28,3 & 99,5 \\
\hline & край & 57,5 & 42,5 & 100,0 & & край & 57,9 & 42,1 & 100,0 \\
\hline \multirow{2}{*}{ K161_71 } & центр & 73,0 & 26,5 & 99,5 & \multirow{2}{*}{ K163_71 } & центр & 67,5 & 32,1 & 99,6 \\
\hline & край & 60,1 & 39,9 & 100,0 & & край & 53,5 & 46,5 & 100,0 \\
\hline K161_71 & центр & $\begin{array}{l}71,6 \\
587\end{array}$ & 27,6 & $\begin{array}{c}99,2 \\
1000\end{array}$ & K163_250 & центр & 67,6 & 31,5 & $\begin{array}{c}99,1 \\
1000\end{array}$ \\
\hline
\end{tabular}

Особенности морфологии и химического состава изученных частиц золота позволяют предполагать их первичную эндогенную природу. Говорить о степени гипергенного изменения золотин достаточно сложно из-за отсутствия у них четко проявленных признаков вторичных преобразований. В экзогенных условиях основные изменения первичного золота связаны с его «облагораживанием» (повышением пробности), укрупнением, образованием высокопробных кайм и микропрожилков [4]. Однако по химическому составу все изученные частицы золота из элювия характеризуются наличием низкопробных кайм, хотя в зоне гипергенеза серебро более подвижно и проявляет тенденцию обособляться от $\mathrm{Au}$. Тем не менее, подобные случаи описаны в литературе и объясняются исследователями особенностями физикохимических обстановок растворения, миграции и отложения $\mathrm{Au}$ и $\mathrm{Ag}$ в различных частях коры выветривания [5]: высокая подвижность серебра в окислительных условиях приводит к очищению золота от примесей в верхних горизонтах. В нижних частях, где преобладают восстановительные условия, и миграция элементов в растворах ограничена, $\mathrm{Au}$ при отложении насыщается большим количеством примесей, в том числе и Ag.

Однако наличие низкопробных кайм в золотинах элювиальных отложений рудопроявления Полярная Надежда связано, по нашему мнению, не с гипергенными процессами, а обусловлено особенностями эндогенного распределения $\mathrm{Au}$ и $\mathrm{Ag}$ в коренных рудах. Снижение пробности золота от нижних гори- зонтов к верхним в пределах рудных тел известно давно и описано на многих месторождениях [4]. Вероятнее всего, образование элювия изученного рудопроявления происходило именно за счет разрушения рудных тел с эндогенным низкопробным золотом.

Более достоверным, чем наличие низкопробных кайм, признаком вторичного изменения золота в рассматриваемых отложениях является наличие в отдельных частицах микропрожилков высокопробного золота. Их возникновение связывается с перегруппировкой $\mathrm{Au}$ в процессе удаления содержавшегося в золотинах газа с самозалечиванием мельчайших освобождавшихся межзерновых полостей [4].

Таким образом, подавляющая масса золота, присутствующая в элювиальных отложениях зоны гидролиза золото-полиметаллических руд рудопроявления Полярная Надежда, находится в форме первичных выделений, лишь частично измененных гипергенными процессами. При этом более $90 \%$ золотин относится к группе мелких и тонких $(<50 \mu \mathrm{m})$, однако в случае присутствия в изученных пробах единичных крупных частиц золота $(\sim 100 \mu \mathrm{m})$, они вносят наибольший вклад в суммарное содержание металла - от 60 до $80 \%$.

Формы нахождения золота в элювиальных отложениях рудопроявления Иочиминское исследовались в геохимической пробе, отобранной из рыхлых отложений зоны окисления (надрудного остаточного ореола рассеяния). При этом основное внимание было уделено фракции размерностью < $80 \mu$ м, которая по результатам ранее проведенных исследований [6] 
характеризуется максимальными содержаниями золота - 10-21 г/т.

Проведенные исследования показали, что золото в изученных отложениях присутствует в форме: 1) субмикроскопических включений в зернах кварца; 2) тончайших (< $2 \mu$ м) плёнок вдоль трещин и других дефектов в структуре гидрогётита и 3) свободных гипергенных золотин.

Наблюдаемые структурные взаимоотношения $\mathrm{Au}$ и гидроокислов железа (рис. 3) однозначно указывают на вторичную гипергенную природу золота, которое в экзогенных условиях соосаждалось вместе с гидрогётитом. Генезис тонкодисперсного золота в кварце менее однозначен: оно может быть как остаточным гипогенным, мигрировавшим механическим путем в составе обломков кварцевых зерен, так и результатом коагуляции коллоидов золота в рыхлых отложениях зоны гипергенеза.

Содержание золота в кварце и новообразованном гидрогётите из рыхлых отложений варьирует от 400 г/т до 900 г/т, но в большинстве случаев не превышает 500 г/т (табл. 6).

Единичная частица свободного самородного золота, присутствующая в выделенном из остатков фракции 63-80 нм гравиконцентрате, характеризуется неправильной формой и размером $25 \times 36 \times 36 \mu$ м (рис. 4).
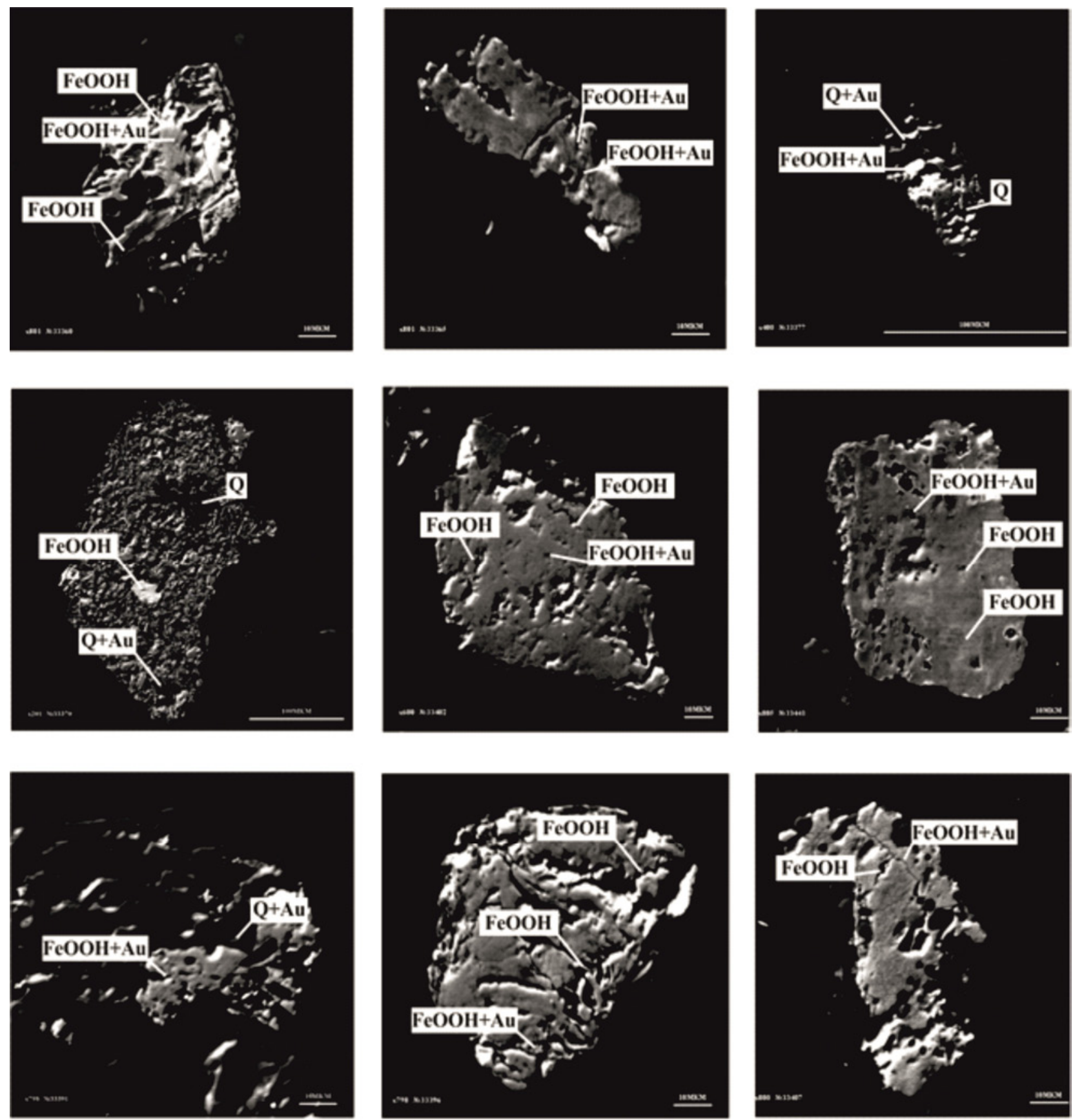

Puc. 3. Вторичное сорбционное золото в дефектах структур новообразованного гидрогётита. Рудопроявление Иочиминское (проба 1-08-05). 
Таблица 6

Содержание золота в минералах из рыхлых отложений рудопроявления Иочиминское (проба 1-08-05), (\% вес.)

\begin{tabular}{|c|c|c|c|c|c|}
\hline Минерал & $\mathrm{Au}$ & $\mathrm{SiO}_{2}$ & $\mathrm{Fe}_{2} \mathrm{O}_{3}$ & $\mathrm{Cr}_{2} \mathrm{O}_{3}$ & Сумма \\
\hline Кварц & 0,06 & 85,33 & 10,54 & 3,70 & 99,62 \\
\hline$-/ /-$ & 0,05 & 100,6 & 0,22 & 0,50 & 101,37 \\
\hline$-/ /-$ & 0,05 & 100,28 & 0,04 & 0,89 & 101,26 \\
\hline Гидрогётит & 0,05 & 7,70 & 74,62 & 0,63 & 83,00 \\
\hline$-/ /-$ & 0,05 & 9,35 & 73,21 & 2,56 & 85,16 \\
\hline$-/ /-$ & 0,06 & 5,35 & 78,15 & 1,51 & 85,07 \\
\hline$-/ /-$ & 0,09 & 6,46 & 74,68 & 4,72 & 85,50 \\
\hline$-/ /-$ & 0,06 & 3,79 & 80,24 & 1,87 & 85,96 \\
\hline$-/ /-$ & 0,07 & 6,07 & 78,38 & 0,86 & 85,39 \\
\hline$-/ /-$ & 0,05 & 6,07 & 74,01 & 0,95 & 81,08 \\
\hline$-/ /-$ & 0,08 & 3,91 & 77,91 & 0,34 & 82,24 \\
\hline$-/ /-$ & 0,04 & 5,54 & 70,99 & 3,46 & 80,03 \\
\hline$-/ /-$ & 0,05 & 3,68 & 71,40 & 0,26 & 75,40 \\
\hline$-/ /-$ & 0,05 & 4,81 & 65,26 & 0,26 & 70,38 \\
\hline$-/ /-$ & 0,04 & 2,91 & 72,56 & 0,73 & 76,24 \\
\hline$-/ /-$ & 0,05 & 4,34 & 77,27 & 1,07 & 82,73 \\
\hline$-/ /-$ & 0,04 & 5,35 & 77,92 & 0,77 & 84,09 \\
\hline$-/ /-$ & 0,05 & 4,34 & 83,61 & 0,06 & 88,07 \\
\hline
\end{tabular}

Наличие подобного мелкого зерна в более крупном гранулометрическом классе обусловлено, вероятно, распадом слипшихся частиц минералов в процессе мокрого ситования при выделении гравиконцентрата. Присутствие в золотине многочисленных каверн, заполненных гидрогётитом, а также отсутствие в ее составе примесей (табл. 7) свидетельствуют в пользу гипергенной природы изученной самородной частицы.

Согласно теоретическим расчетам, вклад единственного относительно крупного зерна золота в суммарное содержание металла в пробе составляет $14 \%$ $(1,41$ г/т при суммарном содержании Аu во фракции 10 г/т), соответственно, на сорбционные и субмикроскопические формы вторичного золота приходится $86 \%$.

Полученные результаты свидетельствуют о том, что в изученных рыхлых отложениях остаточного надрудного ореола присутствуют как зерновые, так и сорбционные формы золота, имеющие вторичную гипергенную природу. При этом основной вклад в суммарное содержание металла в ореоле вносит сорбционное $\mathrm{Au}$.
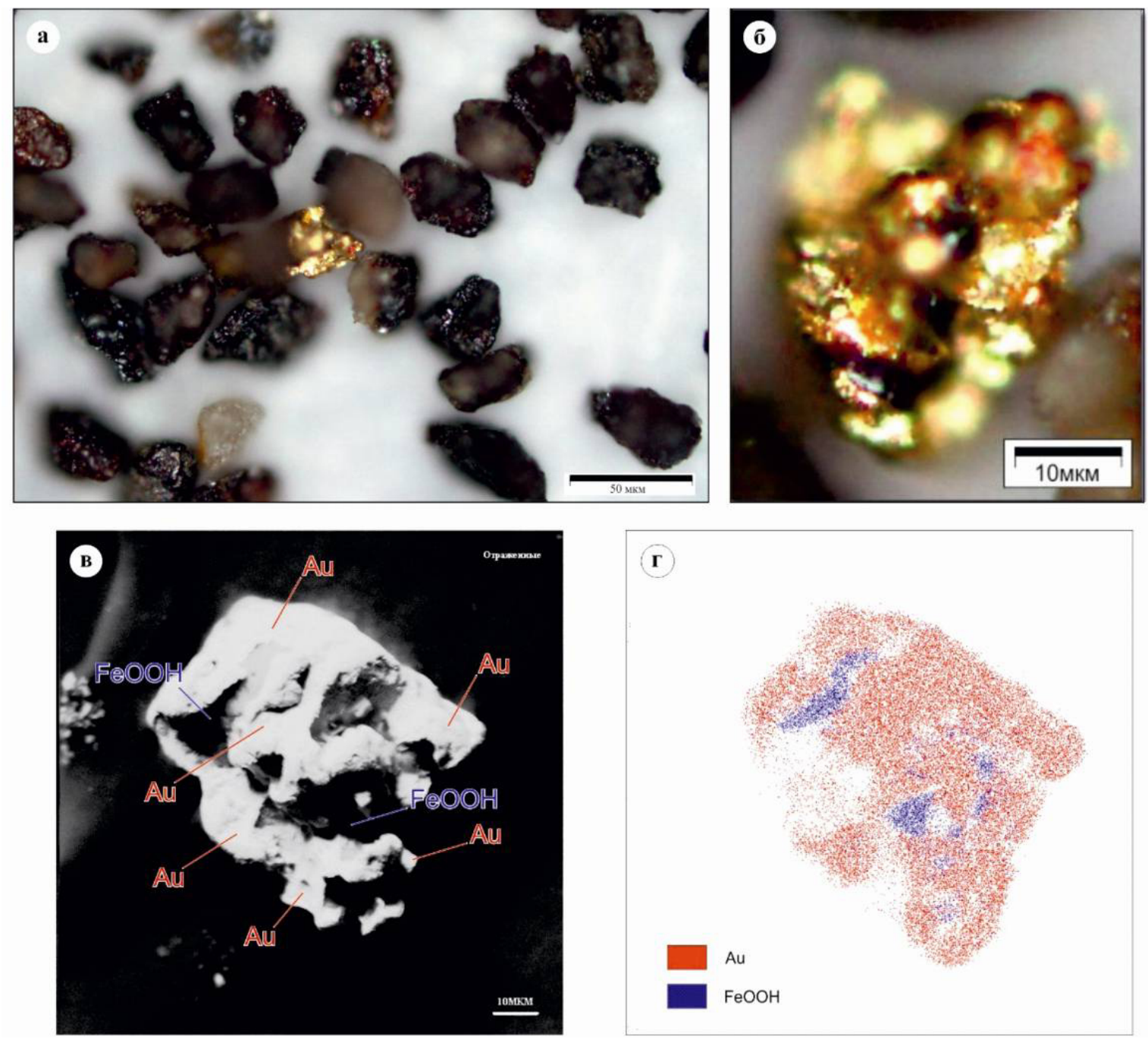

Puc. 4. Гипергенное зерновое золото в элювиальных отложениях зоны окисления рудопроявления Иочиминское (проба 1 08-05): $a-\sigma$ - в проходящем свете; в - в отраженных электронах; 2 - излучение Au L $\alpha$ Fe K $\alpha$. 
Фазовые формы золота в системе коренной источник - вторичный ореол ...

Таблица 7

Химический состав гипергенного самородного золота

из рыхлых отложений рудопроявления Иочиминское (проба 1-08-05), (\% вес.)

\begin{tabular}{|c|c|c|c|c|c|c|c|}
\hline № анализа & $\mathrm{Au}$ & $\mathrm{Ag}$ & Сумма & № анализа & $\mathrm{Au}$ & $\mathrm{Ag}$ & Сумма \\
\hline 1 & 96,66 & 4,34 & 101,00 & 7 & 96,30 & 5,00 & 101,30 \\
\hline 2 & 98,01 & 2,22 & 100,23 & 8 & 98,51 & 2,22 & 100,73 \\
\hline 5 & 97,49 & 3,32 & 100,81 & 10 & 96,85 & 4,39 & 101,24 \\
\hline 6 & 96,51 & 2,82 & 99,33 & 15 & 97,26 & 1,73 & 98,99 \\
\hline
\end{tabular}

Отсутствие в рыхлых отложениях остаточного видимого эндогенного золота обусловлено преобладанием в коренных рудах изученного рудопроявления тонкодисперсного свободного Аu, которое в экзогенных условиях способно легко переходить в раствор или мигрировать в коллоидной форме с последующим закреплением во вторичных формах.

Проведенные исследования, а также анализ многочисленных литературных данных [4-21 и др.] позволяют говорить о том, что в коренных породах золото может присутствовать в зерновой, изоморфной (структурной, неструктурной) и сорбционной формах. Их соотношение зависит от состава золотосодержащих руд, в первую очередь от количества присутствующих сульфидов. В элювиальных отложениях вся масса золота концентрируется в виде самородного металла, образуя либо свободные зерна, либо тонкодисперсные частицы, сорбированные глинистыми минералами, гидроокислами железа, марганца, органикой и др.

На основе имеющихся данных о формах нахождения золота в различных геологических средах, а также особенностях его поведения в различных физикохимических условиях предложены модели перераспределения фазовых форм Аи от рудного коренного источника в рыхлые отложения при формировании АГХП.

\section{Модель перераспределения фазовых форм золота от рудного коренного источника в рыхлые отложения при формировании АГХП \\ сульфидсодержащих золоторудных объектов}

Коренной источник. В сульфидсодержащих рудах основными формами нахождения золота являются примеси в сульфидах, главным образом, в пирите и арсенопирите. Примеси представлены видимыми включениями самородного металла (зерновая форма) и «невидимым» (структурным, неструктурным) золотом (сорбционная форма). Среди редко встречающихся свободных выделений самородного Аu по размеру преобладают тонкодисперсные и мелкие частицы (до $90 \%$ от общего количества выделений) [7]. В первичных ореолах сульфидсодержащих руд все золото концентрируется в сульфидах.

В случае метаморфических преобразований коренных пород и руд происходит перераспределение золота, однако формы его нахождения остаются прежними, меняется только их количественное соотношение. Так, в низкотемпературных условиях зеленосланцевой фации пирит и арсенопирит очищаются от «невидимого» золота, которое группируется на гранях крис- таллов в виде более крупных выделений. Укрупняются и частицы самородного золота, т.е. роль тонкодисперсного и субмикроскопического Аu резко сокращается. В условиях эпидот-амфиболитовой и амфиболитовой фаций метаморфизма наблюдается обратная картина: за счет диссоциации и разложения сульфидов золото высвобождается, в основной своей массе мигрирует в составе жидкофлюидной фазы в области более низкотемпературного метаморфизма, в меньшей степени концентрируется в виде изоморфной примеси в пирротине или магнетите. Видимые свободные выделения самородного золота под действием высоких температур распадаются на более мелкие частицы.

Элювиальные отложения (остаточный ореол рассеяния). В зоне гипергенеза в благоприятных условиях (теплый и влажный климат, наличие пострудных деформаций и др.) за счет взаимодействия насыщенных кислородом и углекислотой поверхностных вод с сульфидсодержащими рудами формируются кислые растворы. Дальнейшее их просачивание в более глубокие горизонты приводит к разложению сульфидов и переводу содержащегося в них золота в растворенное состояние в виде комплексных соединений типа $\mathrm{Au}(\mathrm{OH})_{2}^{-}, \mathrm{Au}(\mathrm{OH}) \mathrm{Cl}^{-}, \mathrm{Au}(\mathrm{OH}) \mathrm{Br}^{-}, \mathrm{AuCl}_{2}^{-}, \mathrm{AuJ}_{2}^{-}$и $\mathrm{AuBr}_{2}^{-}$. Поровые растворы, обогащенные галогенами (хлором, бромом, йодом), поступая в инфильтрационные воды, в присутствии разлагающихся сульфидов повышают растворимость золота на несколько порядков. При этом наиболее легко переходят в раствор тонкодисперсные и субмикроскопические частицы $\mathrm{Au}$, мелкие и крупные выделения практически не растворяются.

Большая часть вновь образованных золотонасыщенных растворов просачивается в нижние горизонты коры выветривания (зона гидролиза), где при смене окислительных условий на восстановительные, ниже уровня грунтовых вод происходит разрушение комплексных соединений и восстановление золота до металлического состояния с образованием новых гипергенных форм. При этом, выпадая из растворов, золото часто укрупняется. Относительно крупные частицы эндогенного золота в случае трещиноватости вмещающих пород могут частично «проваливаться» вниз, однако подобная механическая миграция - довольно редкое явление [5]. В подавляющем большинстве случаев основная масса макроскопического Аu остается в верхних горизонтах элювиальных отложений.

Результатом химической миграции золота в экзогенных условиях является формирование в зоне 
гидролиза сульфидсодержащих руд горизонтов вторичного обогащения, в которых золото присутствует преимущественно в двух формах: 1) частиц самородного металла, сохранивших основные черты первичных выделений, но частично измененных гипергенными процессами и 2) новообразованных выделений. Последние обычно представлены тонкодисперсными губчатыми, комковидными, дендритовидными золотинами, реже - хорошо образованными кристаллами (октаэдрами и кубоктаэдрами), а также вкрапленностью, пленками, включениями губчатых обособлений в новообразованных гидроокислах железа.

По соотношению частично измененного эндогенного и гипергенного золота в зонах вторичного обогащения, вероятно, преобладает последнее. Это обусловлено тем, что, как отмечалось ранее, основную массу металла в коренных сульфидсодержащих рудах составляет тонкодисперсное и «невидимое» золото. Последнее, по выражению В. М. Крейтера, представляет собой «миграционную часть золотого фонда месторождений» [5]. Говоря о количественном соотношении зерновых (независимо от генезиса) и сорбционных форм золота, большинство исследователей сходятся во мнении, что в горизонтах вторичного обогащения преобладает видимое золото.

Верхние горизонты элювиальных отложений (зона окисления) за счет растворения и выноса основной массы тонкодисперсного и «невидимого» золота оказываются, в целом, обеднены металлом. Однако и здесь происходит отложение новообразованного золота из растворов в виде кристаллов или пленок [5].

Рассмотренные особенности поведения золота в гипергенных условиях обуславливают присутствие в рыхлых отложениях остаточных ореолов рассеяния сульфидсодержащих золоторудных месторождений как сорбционных, так и зерновых форм золота. Их соотношение определяется длительностью и интенсивностью протекания окислительных процессов: чем длительнее выветривание, тем больше тонкодисперсного золота, способного растворяться, выносится из верхних горизонтов элювиальных отложений в нижние, и тем меньше роль сорбционных форм золота в формировании остаточных ореолов.

Говоря о присутствии в зерновых частицах как остаточного эндогенного, так и новообразованного Au во вторичных ореолах, необходимо отметить, что дальность механического переноса такого золота не значительна, поэтому область распространения его крупных зерновых форм в рыхлых отложениях ограничивается, главным образом, контурами коренного источника. Однако в процессе разрушения пород и руд крупные выделения золота истираются с образованием более тонких частиц, масштабы горизонтального перемещения которых значительно больше. Таким образом, непосредственно над рудными телами в рыхлых отложениях будут преобладать наиболее крупные частицы зернового золота, размеры и количество которых по мере удаления от коренного источника постепенно уменьшаются.
Основным источником подвижного золота и его сорбционных форм в остаточных ореолах рассеяния служат реликтовые золотосодержащие сульфиды. Следует отметить, что транспортировка растворенного $\mathrm{Au}$ вряд ли осуществлялась на значительные расстояния, так как золотоносные растворы всех типов крайне неустойчивы, а факторы, способствующие осаждению золота, многочисленны [4]. Широкое развитие в рыхлых отложениях веществ, активно сорбирующих золото, быстрое изменение кислотно-щелочных свойств растворов и т.п. приводят к закреплению металла в виде субмикроскопических частиц на поверхности глинистых минералов, органики, гидроокислов железа и др. вблизи коренного источника. Однако в сорбированном состоянии в составе более крупных выделений, например, гидрогётита, перенос золота может продолжаться механическим путем. Кроме того, при возникновении благоприятных условий на пути механической миграции сорбированные частицы золота вновь переходят в раствор и переносятся в растворенном виде. Обусловлено это тем, что, в отличие от большинства других элементов, для которых растворение приводит к необратимым преобразованиям их минеральной и химической формы, для золота мигрирующие формы обратимы, и оно может неоднократно выпадать из растворов в самородном виде [8]. Подобное многократное растворение в сочетании с механической миграцией приводит к перемещению участков концентрации сорбционных форм золота на более дальние расстояния относительно коренного источника по сравнению с зерновыми частицами (рис. 5a).

Делювиальные отложения (наложенный ореол рассеяния). Известно, что, в отличие от остаточных ореолов, образованных за счет рудных зон, существовавших в их контуре до выветривания, наложенные ореолы образуются в чехле аллохтонных отложений путем поступления рудных элементов из глубины [9-11].

Особенности миграции золота позволяют предполагать, что его движение в вертикальном направлении осуществлялось, главным образом, в форме коллоидных или истинных растворов, однако в сульфидсодержащих месторождениях коллоиды золота крайне неустойчивы. Следовательно, основной формой миграции золота в рассматриваемом случае выступают растворимые комплексные соединения, а основной формой концентрации сорбционная (рис. 5а). При этом, перемещение Аu представляет собой неоднократное повторение этапов перехода субмикроскопического золота в раствор $\rightarrow$ движения вверх в составе растворов по системе капилляров $\rightarrow$ осаждения в форме сорбционных частиц $\rightarrow$ переноса механическим путем $\rightarrow$ растворения $\rightarrow$ движения вверх и т.д. Необходимо отметить, что непосредственно над коренным источником, где концентрация золота в растворенном состоянии максимальная, для наложенных ореолов велика вероятность выпадения $\mathrm{Au}$ и в форме новообразованных зерновых частиц. 
$\mathbf{a}$

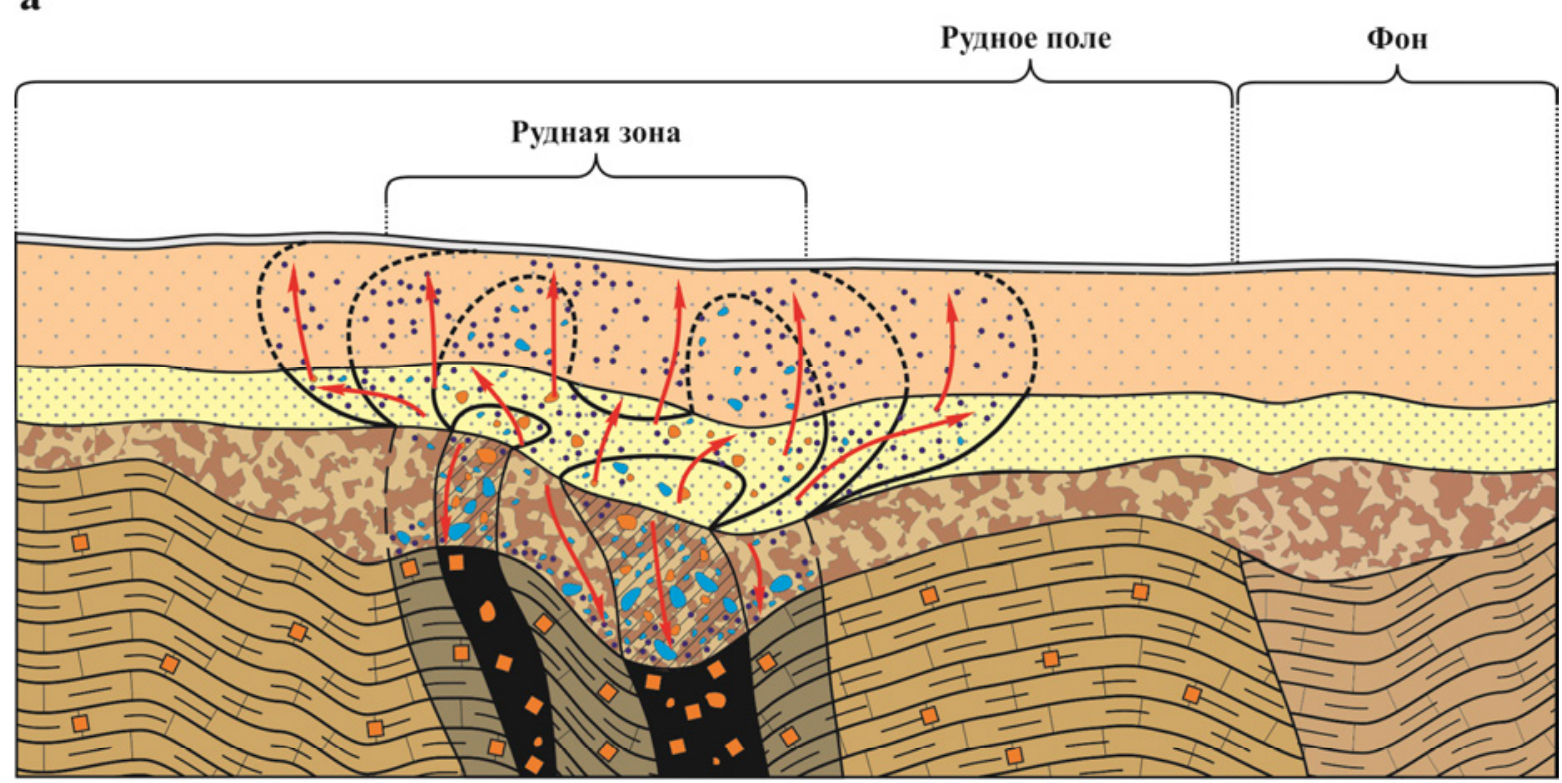

б

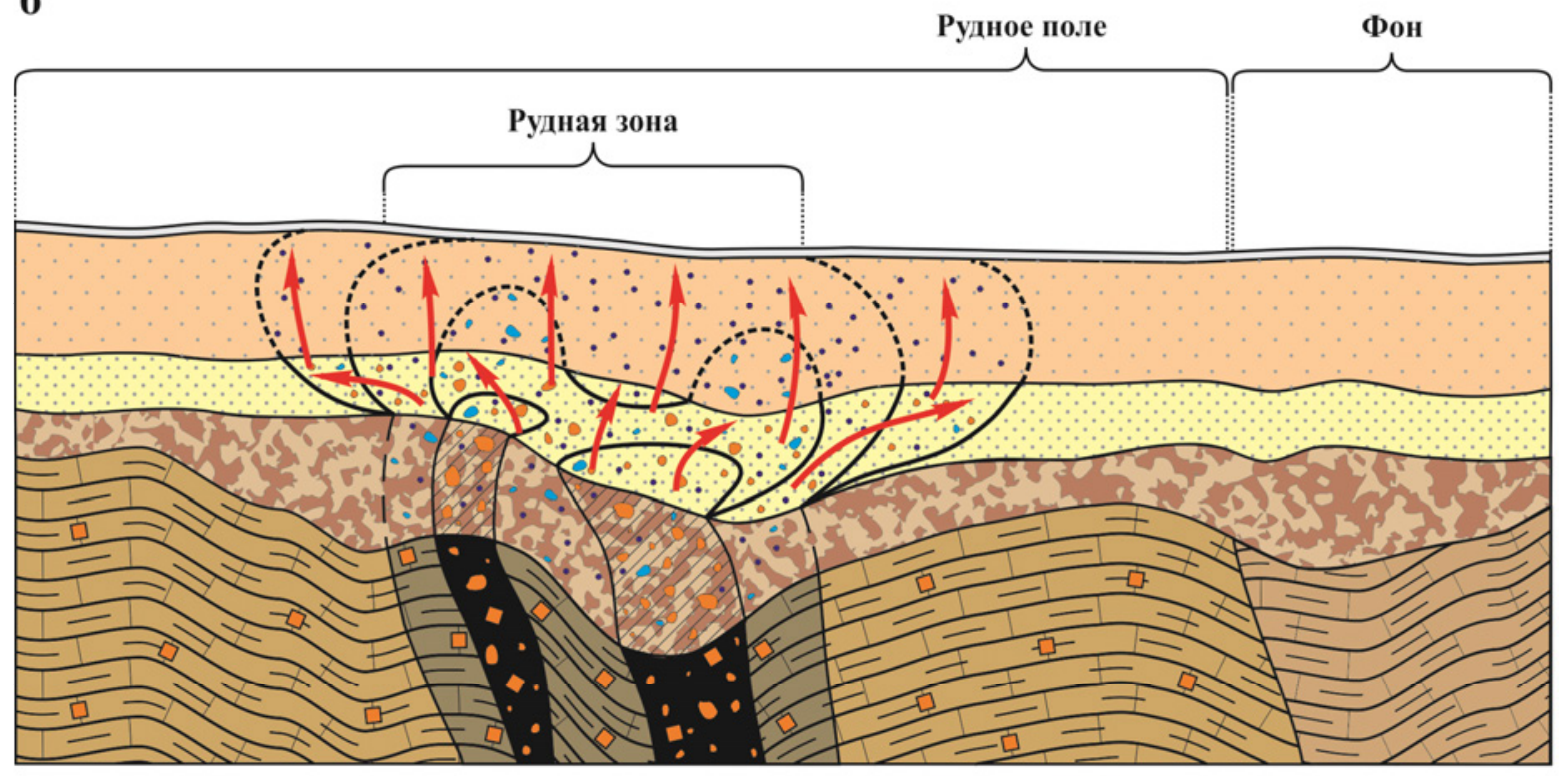

УСЛОВНЫЕ ОБОЗНАЧЕНИЯ

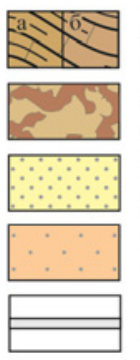

Коренные породы:

a-рудовмещаюице; б - фоновые

Элювиальные отложения зоны гидролиза

Элювиальные отложения

зоны окисления

Делювиальные отложения

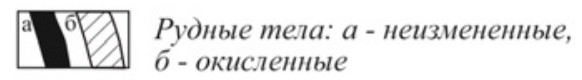

a б Первичные ореолы (а) и их

1 контуры в зоне окисления (б)

$\checkmark$ Остаточный ореол рассеяния

Детовиальные оmломсени

…… Наложенный ореол рассеяния

Почва

Основные направления миграции элементов

Фазовые формы нахождения золота

Эндогенное

$\diamond \diamond$ Тонкодисперсное в сульфидах

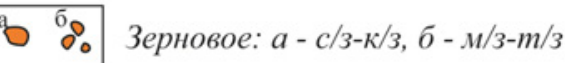

Гипергенное

a ${ }^{6} \circ$ Зерновое: $a-c / 3-\kappa / 3, \sigma-м / 3-m / 3$

$\because \because$ Сорбционное

Pис. 5. Модели перераспределения фазовых форм золота по направлению от коренного источника в рыхлые отложения при формировании АГХП: $a$ - сульфидсодержащих; $\sigma$ - мало-, убогосульфидных золоторудных месторождений. 
Возможность попадания из сульфидсодержащих руд в делювиальные отложения зерновых эндогенных форм золота существует (например, в результате механической миграции за счет деятельности землероющих и беспозвоночных животных), однако она во многом зависит от содержания свободных частиц золота в коренных источниках. В случае если количество видимого самородного эндогенного золота, достаточно крупного, чтобы не раствориться полностью в зоне окисления, не значительно, присутствие зерновых эндогенных форм Аu в составе наложенных ореолов маловероятно.

\section{Модель перераспределения фазовых форм золота от рудного коренного источника в рыхлые отложения при формировании АГХП мало- и убогосульфидных золоторудных объектов}

Коренной источник. В отличие от сульфидсодержащих месторождений, для мало- и убогосульфидных руд характерно присутствие золота, в большей степени, в форме видимого свободного самородного металла, а также собственных минеральных соединения (теллуридов, селенидов и др.). Соотношение среднего-крупного и тонкого-мелкого золота для малосульфидной формации составляет примерно $70 \%$ и $30 \%$ соответственно, для убогосульфидной - $30 \%$ и $70 \%$ [7]. Несомненно, золото находится в рудах и в форме видимых и «невидимых» примесей в сульфидах, однако незначительное содержание последних определяет резко подчиненную роль в коренных малосульфидных источниках безминеральной формы золота. В первичных ореолах мало- и убогосульфидных типов оруденения соотношение форм нахождения золота сдвигается только в сторону увеличения количества тонко-мелко-зернистых выделений.

Особенности поведения золота в процессе метаморфических преобразований рассматриваемых типов руд в целом аналогичны таковым для сульфидсодержащих месторождений. Отличие заключается только в резко подчиненной роли сульфидов и, как следствие, в незначительности масштабов перераспределения золота за счет диссоциации и десульфидизации пирита и арсенопирита. С низкотемпературным метаморфизмом малосульфидных руд связано увеличение размеров выделений самородного золота, средне-, высокотемпературные воздействия приводят к разукрупнению частиц $\mathrm{Au}$ и их дальнейшему рассеиванию в кварце, карбонатах и др.

Элювиальные отложения (остаточный ореол рассеяния). Особенности минерального состава мало- и убогосульфидных руд обуславливают формирование в зоне гипергенеза преимущественно нейтральнощелочных инфильтрационных вод. В подобных условиях золото в основной свое массе остается инертным, образуя лишь подчиненное количество растворимых комплексных соединений типа $\mathrm{AuS}^{-}$или, в случае золото-сурьмяных и золото-мышьяковых руд, $\left[\mathrm{Au}\left(\mathrm{AsS}_{2}\right)\right]^{0},\left[\mathrm{Au}\left(\mathrm{SbS}_{3}\right)\right]^{2-}$ и др. В связи с этим для зоны гипергенеза мало- и убогосульфидных руд главенст- вующую роль в переносе золота приобретают механические взвеси и коллоидные формы.

В виде механических взвесей мигрируют, как правило, тонко-, мелко-, средне- и крупнозернистые золотины, осаждаясь на механических барьерах в зерновой форме. Именно золото-кварцевые коренные месторождения являются основным источником формирования россыпей. Субмикроскопические выделения золота образуют коллоидные частицы, заряженные обычно отрицательно. В условиях обилия в растворе защитных коллоидов, предохраняющих золь $\mathrm{Au}$ от коагуляции (частицы кремнезема) золото может мигрировать на значительные расстояния и концентрироваться как в сорбированном виде, так и в форме самостоятельных вторичных выделений. В перегруппировке и создании локальных концентраций коллоидного золота в зоне гипергенеза возможно принимают участие и бактерии [12].

Собственные минералы золота (преимущественно теллуриды) в зоне гипергенеза превращаются в агрегаты тонкозернистого «горчичного» золота, хлораргирита, теллуритов и теллуратов $\mathrm{Fe}, \mathrm{Cu}, \mathrm{Pb}$. Нередко процессы разложения и окисления сложные и многоступенчатые. Так, например, сильванит на первой стадии окисления превращается в гипергенный петцит + «горчичное» золото + теллурит (1):

$$
3 \mathrm{AuAgTe}_{4} \rightarrow 2 \mathrm{Au}+\mathrm{AuAg}_{3} \mathrm{Te}_{2}+10 \mathrm{TeO}_{2}
$$

На второй стадии петцит превращается в гипергенный гессит + «горчичное» золото + теллурит (2):

$$
2 \mathrm{AuAg}_{3} \mathrm{Te}_{2} \rightarrow 2 \mathrm{Au}+3 \mathrm{Ag}_{2} \mathrm{Te}+3 \mathrm{TeO}_{2}
$$

Специфика минерального состава мало- и убогосульфидных руд, а также особенности миграции Аu в нейтрально-щелочных условиях обуславливают отсутствие в коре выветривания золото-кварцевых и золото-серебряных месторождений горизонтов заметного вторичного химического обогащения золота. Эти же факторы определяют и формы нахождения $\mathrm{Au}$ в элювии в виде: 1) частиц, полностью сходных с золотом первичных руд; 2) новообразованных выделений (как сорбционных, так и самостоятельных).

Таким образом, в остаточных ореолах рассеяния мало- и убогосульфидных золоторудных месторождений будут присутствовать и зерновые, и сорбционные частицы Au. Однако их соотношение существенно отличается от такового для АГХП богатых сульфидами коренных источников. Так, для руд со значимым количеством средних и крупных частиц золота, которые не подвергаются существенным гипергенным изменениям, ведущая роль в формировании остаточных ореолов принадлежит зерновым формам Au. В свою очередь для руд с преобладающим тонко-мелкозернистым золотом, легко мигрирующим в виде коллоидов, в составе остаточных ореолов, наряду с зерновыми формами, большую роль будет играть сорбционное $\mathrm{Au}$ (рис. 5б), как это было показано на примере рудопроявления Иочиминское.

Делювиальные отложения (наложенный ореол рассеяния). При формировании наложенных ореолов 
рассеяния, образующихся над мало- и убогосульфидными коренными источниками, ведущая роль в миграции золота принадлежит, вероятно, коллоидным растворам. Учитывая тот факт, что за счет коагуляции золотоносных гелей возможно образование не только сорбционных, но и самостоятельных частиц вторичного $\mathrm{Au}$, можно предполагать присутствие в аллохтонных отложениях и новообразованных зерновых форм золота. Кроме этого, механическим путем в на- ложенные ореолы могут попадать и зерновые частицы эндогенного остаточного золота, содержание которых в коренных малосульфидных рудах существенно выше, чем в сульфидсодержащих (рис. 5б).

В целом рассмотренные выше модели позволяют в интегральной системе выделить принципиальную схему перераспределения фазовых форм золота в системе коренной источник - вторичный ореол (табл. 8).

Принципиальная схема перераспределения фазовых форм золота в системе коренной источник - вторичный ореол

\begin{tabular}{|c|c|c|c|c|c|c|}
\hline \multirow{3}{*}{$\begin{array}{l}\text { Элементы } \\
\text { системы }\end{array}$} & \multicolumn{6}{|c|}{ Фазовые формы золота } \\
\hline & \multicolumn{4}{|c|}{ Минеральная (зерновая) } & \multicolumn{2}{|c|}{ Изоморфная, сорбционная } \\
\hline & $\begin{array}{l}\text { Свободное } \\
\text { эндогенное }\end{array}$ & $\begin{array}{c}\text { Свободное } \\
\text { гипергенное }\end{array}$ & $\begin{array}{l}\text { Собственные } \\
\text { минералы Au }\end{array}$ & $\begin{array}{c}\text { Видимые } \\
\text { включения в } \\
\text { сульфидах }\end{array}$ & $\begin{array}{l}\text { «Невидимая» } \\
\text { примесь в } \\
\text { сульфидах }\end{array}$ & Сорбционное \\
\hline \multicolumn{7}{|c|}{ Сульфидсодержашие руды } \\
\hline $\begin{array}{c}\text { Делювиальные } \\
\text { отложения } \\
\text { (наложенный ореол) }\end{array}$ & & \pm & & & & +++ \\
\hline $\begin{array}{c}\text { Элювиальные } \\
\text { отложения - зона } \\
\text { окисления } \\
\text { (остаточный ореол) }\end{array}$ & & ++ & & & & +++ \\
\hline $\begin{array}{c}\text { Элювиальные } \\
\text { отложения - } \\
\text { зона гидролиза } \\
\end{array}$ & \pm & +++ & & & & ++ \\
\hline $\begin{array}{l}\text { Коренные породы } \\
\text { (первичный ореол) }\end{array}$ & + & & + & ++ & +++ & \\
\hline \multicolumn{7}{|c|}{ Мало-, убогосульфидные руды } \\
\hline $\begin{array}{c}\text { Делювиальные } \\
\text { отложения } \\
\text { (наложенный ореол) }\end{array}$ & + & + & & & & +++ \\
\hline $\begin{array}{c}\text { Элювиальные } \\
\text { отложения - зона } \\
\text { окисления } \\
\text { (остаточный ореол) } \\
\end{array}$ & +++ & \pm & & & & ++ \\
\hline $\begin{array}{c}\text { Элювиальные } \\
\text { отложения - } \\
\text { зона гидролиза } \\
\end{array}$ & +++ & + & & & & + \\
\hline $\begin{array}{l}\text { Коренные породы } \\
\text { (первичный ореол) }\end{array}$ & +++ & & + & \pm & \pm & \\
\hline
\end{tabular}

Примечание: роль фазовой формы в общем содержании $\mathrm{Au}$ 土 резко подчиненная; + подчиненная; ++ существенная; +++ преобладающая

\section{Заключение}

Таким образом, разработанные модели перераспределения фазовых форм золота от рудного коренного источника в рыхлые отложения при формировании АГХП показывают, что в пределах рудных зон непосредственно над коренным источником, как в элювиальных, так и в делювиальных отложениях будут присутствовать и зерновые, и сорбционные формы золота. По мере удаления от рудного объекта роль сорбционных форм возрастает, а за пределами рудного поля в рыхлых отложениях могут наблюдаться только ксеногенные зерновые частицы (рис. 6).

Соотношение зернового (эндогенного и гипергенного) и сорбционного Аu в рыхлых отложениях зависит от близости коренного источника, состава руд (сульфидсодержащие, убого-, малосульфидные), преобладающей в них формы золота (свободное, видимое, субмикроскопическое и др.) и ландшафтно-геохимических особенностей зоны гипергенеза (степень кислотности и насыщенности галогенами поверхностных вод, дренирующих месторождение).

В связи с этим методика опробования рыхлых образований и анализируемая фракция должны выбираться для каждой поисковой территории индивидуально с учетом фазовых форм нахождения $\mathrm{Au}$, характерных для данного геолого-промышленного типа, и их соотношения в конкретных ландшафтно-геохимических условиях. 


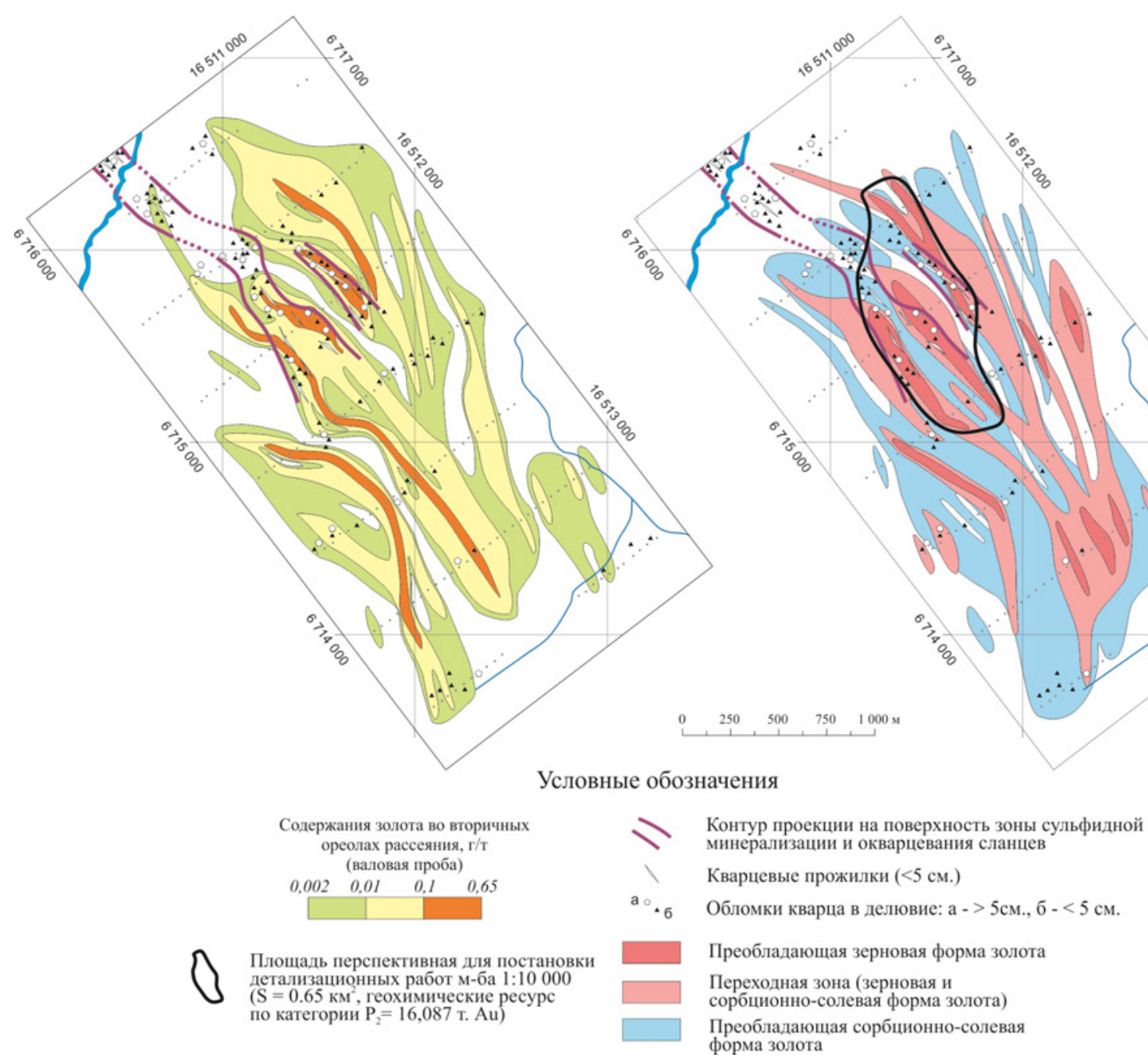

Pис. 6. Распределение фазовых форм золота во вторичных ореолах рассеяния рудопроявления Иочиминское (масштаб 1 : $25000)$

Авторы выражают благодарность Н.С. Смирновой и Д. И. Смирнову за предоставленные материалы по рудопроявлению Полярная Надежда.

\section{ЛИТЕРАТУРА}

1. Соколов, С. В. Временные методические указания по проведению геохимических поисков на закрытых и полузакрытых территориях/ С. В. Соколов // ФГБУ ВСЕГЕИ. Санкт-Петербург, 2005 г. -98 с.

2. Кнауф, В. В. О достоверности отображения природных структур распределения рудных компонентов в аномалиях литогеохимической съемки/ В. В. Кнауф // «Прикладная геохимия» - 2008. - Вып. 8. - С. 210-220.

3. Orientation study of strategic deep penetration geochemical methods in the central Kyzylkum desert terrain, Uzbekistan/ X. Xuejing [et al.] // Journal of Geochemical Exploration. - 1999. V. 66. - P. 135-143.

4. Петровская, Н. В. Самородное золото/ Н. В. Петровская / М.: Наука, 1973. - 348 с.

5. Поведение золота в зоне окисления золото-сульфидных месторождений / В. М. Крейтер [и др.] / М.: Госгеолтехиздат, $1958 .-268 \mathrm{c}$.

6. Кременецкий, $A$. А. Современные подходы в геохимических методах поиска твердых полезных ископаемых и углеводородов / А. А. Кременецкий, Т. Н. Полякова, А. Г. Пилицын // Материалы 1-ой научно-практической конференции «Геология, геофизика и минеральное сырье Сибири» - г. Новосибирск, 2014 г. - С. 40-44.

7. Wang, X. Concepts for geochemical gold exploration based on the abundance and distribution of ultrafine gold / X. Wang, X. Xie, Y. Shengyong // «J. Gechem. Exp.». - 1995. - V.55. P. 329-336.

8. Кузьминых, В. М. Миграция и накопление золота при гипергенных процессах/ В. М. Кузьминых, А. П. Сорокин // Вестник ДВО РАН. - 2004 - №2. - С. 113-119.

9. Матвеев, А. А. Геохимические методы поисков месторождений полезных ископаемых / А. А. Матвеев, А. П. Соловов / Изд-во «КДУ», $2011-564$ с.

10. Савко, А. Д. Ультратонкое золото / А. Д. Савко, Л. Т. Шевырев / Труды НИИ геологии Воронеж. гос. ун-та. Вып. 6. Воронеж: Изд-во Воронеж. гос. ун-та, 2001 - 151 с.

11. Савко, А. Д. Эксгаляционно-осадочная металлоносность Воронежской антеклизы - новые горизонты поисков рудных месторождений в осадочном чехле. - Статья 1. Интерметаллиды: Локализация, типы, состав / А. Д. Савко, Л. Т Шевырев, В. В. Лоскутов // Вестн. Воронеж. гос. ун-та. - Сер. геол. - Воронеж- 1999. - № 7. -С. 139-155.

12. Ляликова, Н. Н. Роль микроорганизмов в образовании 
и разрушении сульфидов в рудах месторождений / Н. Н. Ляликова // Геол. рудн. местор. - 1970. - Вып. 12. - № 1. C. 63-73.

13. Некрасов, И. Я. Геохимия, минералогия и генезис золоторудных месторождений / И. Я. Некрасов // М.: Наука, 1991. - $304 \mathrm{c}$.

14. Спиридонов, Э. М. Обзор минералогии золота ведущих типов $\mathrm{Au}$ минерализации / Э. М. Спиридонов // «Золото Кольского полуострова и сопредельных территорий». 2010. - C. 143-171.

15. Scaini, M. J. Reactions of aqueous Au1+ sulfide species with pyrite as a function of $\mathrm{pH}$ and temperature / M. J. Scaini, G.M. Bancroft, S.W. Knipe // Amer. Miner. - 1998. - V. 83. P. 316-322.

16. Божко, E.Н. Золотоносность Бирримского массива
(Западная Африка) / Е. Н. Божко, А. Д. Савко / Труды НИИ геологии Воронеж. гос. ун-та. - Вып. 33. Воронеж: Изд-во Воронеж. гос. ун-та, $2005-132$ с.

17. Диман, Е.Н. Моделирование на ЭВМ гипергенных процессов / Е. Н. Диман, И. К. Карпов, В. Н. Макаров/ М.: Наука, 1982. - $72 \mathrm{c}$.

18. Росляков, Н. А. Геохимия золота в зоне гипергенеза / Н. А. Росляков / Новосибирск: Наука, 1981 - 238 с.

19. Моисеенко, В.Г. Поведение золота и серебра при осадконакоплении, вулканизме и метаморфизме / В. Г. Моисеенко, М. А. Михайлова, В. Г. Сахно / Наука, Сибирское отд., 1974. - 104 с.

20. Наночастицы благородных металлов в зоне гипергенеза / С. М. Жмодик [и др.] // Геол. рудн. месторожд. - 2012. Том 54. - № 2. - С. 168-183.

\section{Voronezh State University}

Polyakova T. N., Ph.D, associate professor of Geosciences Department, leading research scientist of Federal State Budgetary Institution "Institute of Mineralogy, Geochemistry and Crystal Chemistry of Rare Elements"

E-mail: imgre2010@yandex.ru; Tel.: +7 (903) 850-67-03

Federal State Budgetary Institution "Institute of Mineralogy, Geochemistry and Crystal Chemistry of Rare Elements", Moscow

Pilitsyn A. G., chief of department of "Geology and geochemistry of the Arctic region"

E-mail: allexpil@yandex.ru; Tel.: +7 (495) 443-75-03

Kremenetsky A. A., professor, Counsellor of the Director General

Tel.: +7 (495) 443-94-24

E-mail:nauka@imgre.ru 